\title{
Rural Roads, Poverty, and Resilience: Evidence from Ethiopia
}

Shohei Nakamura (corresponding author), World Bank, 1818 H Street, NW, Washington, D.C., 20433, the United States, snakamura2@worldbank.org,+1-202-473-4200

Tom Bundervoet, World Bank, 1818 H Street, NW, Washington, D.C., 20433, the United States, tbundervoet@worldbank.org

Mohammed Nuru, Afri Geoinformation Engineering, Nifas Silk Lafto Sub City, Woreda-03, House No. 3062, Biisrat Geberiel Area, Addis Ababa, Ethiopia, mohammedgis2000@yahoo.com

Keywords: rural road; poverty; agriculture; weather shocks; Ethiopia

JEL Classifications: O18, R40, I32, Q2

\section{Acknowledgments}

The authors would like to thank Ruth Hill and two anonymous referees for useful comments. The findings, interpretations, and conclusions expressed in this paper are entirely those of the authors. They do not necessarily represent the views of the International Bank for Reconstruction and Development/World Bank and its affiliated organizations, or those of the Executive Directors of the World Bank or the governments they represent.

\section{Introduction}

Transport development is widely considered as a key to economic growth and poverty reduction in the developing world (Berge et al. 2017). As global poverty is increasingly concentrated in Sub- 
Saharan Africa (World Bank 2018a) and the majority of the extreme poor live in rural Africa, it is imperative to ensure rural populations' access to markets. The provision of access to all-weather feeder roads, or rural roads, is expected to raise living standards in poor rural areas by reducing transport costs between villages and markets and thereby generating market activity, affecting input and output prices, and enhancing agricultural production through the increased use of modern technologies and the changes in crop choice (Hine et al. 2016). Rural roads also potentially facilitate structural transformation by facilitating non-farm employment and rural-urban migration. In addition, better connectivity can enhance resilience to covariate shocks by better integrating markets - dissipating price effects of large shocks - and facilitating provision of support to shockaffected communities.

With such expectations of its fundamental role in economic growth, poverty reduction, and resilience, a large amount of money has been invested in the development of rural roads in developing countries. Ethiopia is not an exception; the government has put considerable efforts into rural road development. Under the umbrella of the first Growth and Transformation Program (2010-2015), the government launched an ambitious program, the Universal Rural Road Access Program (URRAP), in 2010 to promote construction and upgrading of more than $70,000 \mathrm{~km}$ of rural roads in the country (World Bank 2018b). The program aims to ensure all rural communities of the country are connected to an all-weather road. The program implementation for the first five years cost 28 billion Ethiopian birr, or US\$1.4 billion (World Bank 2018b).

Despite the scale of investment in rural roads in developing countries and the general consensus on its importance, empirical evidence on the impacts of rural road development has been scarce. Among various methodological challenges in the impact evaluation of rural road programs, endogeneity problems stemming from the non-random placement of rural roads are particularly difficult to deal with (van de Walle 2009; Blimpo, Harding, and Wantchekon 2013; Burgess et al. 2015; Lehne, Shapiro, and Eynde 2018). ${ }^{1}$ Some recent studies focus on India's nationwide rural road program (Pradhan Mantri Gram Sadak Yojana, or PMGSY), which started in 2000 (Asher and 
Novosad 2019; Shamdasani 2016; Aggarwal 2018). They exploit the program's clear criteria for selecting villages, such as population thresholds, in identifying the impacts on agriculture and other outcomes. Unfortunately, such identification strategy cannot be applied to other rural road developments that are not strictly enforced based on objective criteria as in Ethiopia's URRAP.

This study attempts to assess the linkage between the recent rural road development and household welfare, resilience, and economic conditions in Ethiopia by addressing the aforementioned challenges with rich data sets. The analysis focuses on the short-term effects, within four to six years from the road development at the longest. The study period from 2010 to 2016 covers the recent severe El-Nino drought (2015/16), which allows us to examine the role of rural roads in households' ability to cope with severe covariate shocks. This study examines the following key questions. First, to what extent has the development of rural roads been associated with household welfare and economic activities in rural Ethiopia? Second, what role, if any, did rural road development play in moderating the effects of the recent severe El Nino drought (2015/2016)? And third, is the association between improved connectivity and welfare outcomes moderated by baseline connectivity levels (that is, do communities that are very remote to begin with benefit more or less from rural road development)?

The primary empirical approach is difference-in-differences (DID) matching based on road network and household panel data sets. A panel road network database is constructed for multiple years so that changes over time in rural roads and various welfare and economic outcomes can be compared. For the outcome measures, this study relies on the first and last waves of a panel household survey — the Ethiopian Socioeconomic Survey (ESS) — which were carried out in 2012, 2014, and 2016. The timing of the data collection was ideal to assess the short- and medium-term effects of rural roads that have been developed under the URRAP since 2010, including its role in strengthening rural households' resilience to shocks in a particularly shock-prone country. In addition, the ESS covers a large part of rural Ethiopia, which allows this study to explore locational heterogeneity. Combining the road database and the ESS data, this study aims to estimate the 
associations between rural road development and household welfare, resilience, and economic indicators, while reducing as much as possible the potential endogeneity bias due to nonrandom placement of rural roads. The primary strategy is a DID matching approach (Smith and Todd 2005), as used for the impact analysis of rural road access by Lokshin and Yemtsov (2005) and Mu and van de Walle (2011). Despite all these efforts, however, interpreting the results as causal impacts should be avoided due to the nature of the empirical approach. Finally, this study analyzes one of the most relevant outcomes from a poverty reduction perspective: household consumption as a welfare measure.

The results of the econometric analysis suggest that Ethiopia's recent rural road development was associated with a significant increase in household welfare. We estimate that rural road development was associated with 18.6 percent higher household consumption between 2012 and 2016 (or 4.4 percent each year during the period). Given that household consumption levels decreased between 2012 and 2016, both in the "treatment" (households in communities where rural roads were developed) and "comparison" group (in communities which did not benefit from rural road development during the period), this result should be interpreted as rural road development being associated with significant smaller losses in consumption. Consumption gains (or rather, limited consumption losses) were not driven by better-off households, as rural road development was associated with a lower likelihood of remaining in or falling into poverty.

In exploring heterogeneity across intensity of drought-exposure, we find suggestive evidence that newly-developed rural roads helped rural households to better cope with the adverse effects of the drought, though the associations are not always statistically significant. In exploring heterogeneity across baseline levels of remoteness, we find that rural road development tended to be more beneficial for households that were very remote to begin with, a channel that partly runs through increased market orientation of newly-connected farmers in remote places and increased use of agricultural inputs. Rural road development was also positively associated with the likelihood of earning income from wage employment in remote areas, particularly for women and youth. 
Looking deeper into this relationship, we find that the increase in wage employment is mainly due to increased casual wage labor in construction, which may be linked to the development and maintenance of the rural roads themselves.

This study contributes to the literature on the impacts of rural road development. There is a small number of previous studies that evaluate the impacts of rural road development in the developing world. ${ }^{2}$ Khandker, Bakht, and Koolwal (2009) examined the impact of road investments on poverty in Bangladesh, finding the overall effect of road improvement on household consumption to be about 8-10 percent in the project areas. By contrast, a recent study of India's PMGSY program by Asher and Novosad (2019) finds no clear impact on household consumption and agricultural outcomes in connected villages. ${ }^{3}$ Several studies investigate rural roads in Ethiopia. Dercon et al. (2009), using panel data collected in selected villages between 1994 and 2004, found that access to all-weather roads reduced poverty by 6.9 percent and increased consumption growth by 16 percentage points. The findings of a study by Minten, Korn, and Stifel (2013) for northwestern Ethiopia point to the link between higher transport costs and agricultural input prices. Another study by Stifel, Minten, and Koru (2016) suggests that rural feeder roads have internal rates of return of $12-35$ percent.

Another collection of literature to which this study is related is about the impacts of shocks on welfare and poverty, and the role that better connectivity can play in alleviating these impacts. As an agrarian economy dependent on smallholder rain-fed agriculture - located in one of the world's most drought-prone regions - Ethiopia has been historically susceptible to drought and, despite recent economic growth, well-being remains highly vulnerable to the weather. Several previous studies have analyzed the impacts of droughts on consumption (Gao and Mills 2018; Dercon, Hoddinott, and Woldehanna 2005; Fuje 2017), poverty traps (Carter et al. 2007), long-term nutrition outcomes (Dercon and Porter 2014), and asset and wealth and inequality (Little et al. 2006; Thiede 2014). Recently, research focusing on Ethiopia has also shown that better connectivity can help alleviate the negative effects of drought. Hill and Fuje (2018) examine the 
effects of droughts on grain prices in Ethiopia and find that this effect was substantially weaker in the post-2007 period compared to earlier periods, a finding that can partly be explained by better market access through road investments. In a study most related to ours, Hirvonen et al. (2017) find that the 2015/16 El-Nino drought negatively affected child nutrition in places that were poorly connected to the road network, but not in better-connected places. This study contributes to this line of literature by shedding new light on the role of rural connectivity in potentially alleviating the impact of covariate shocks.

The rest of this report is structured as follows. Section 2 reviews recent rural road development in Ethiopia. Section 3 describes the data: the Ethiopia road database and the ESS. Section 4 explains the empirical strategy to identify and estimate effects of rural road developments on welfare and other outcomes. Section 5 reports the estimation results of DID matching models. Finally, Section 6 concludes with a brief summary of the findings and discussion.

\section{Recent rural road development in Ethiopia}

Among several programs that have contributed to recent rural road developments in Ethiopia, the URRAP has provided all-weather connections to rural communities (called "kebeles") at the largest scale since $2010 .{ }^{4}$ Through the upgrading of existing fair-weather access roads or unimproved tracks (that can be unusable during the rainy season), URRAP brings those unclassified roads into the classified network. With $100 \%$ funding from the central government and technical support from regional and zonal governments, districts ("woredas") identify project areas by prioritizing based on population, traffic, and facilities served. However, actual practice of prioritization is unclear and varies regionally. URRAP road construction work is partly the responsibility of the beneficiary communities. Communities in principle carry out site clearance and preliminary earth work as a contribution in kind, yet actual practice differs by regions. On completion of the community works, a URRAP contractor engaged by the woreda carries out the remainder of the construction. ${ }^{5}$ 
During the initial four years of the URRAP program (2010-2014), the Ethiopian government developed rural roads in about 4,000 communities, reaching nearly $20,000 \mathrm{~km}$ in total. The number of communities in which any segment of road was developed or upgraded was 1,850 (or 13 percent of the total number of rural communities) between 2010 and 2012 and 2,205 (15 percent more) between 2012 and 2014. ${ }^{6}$ Among the nine regions analyzed, Oromia, the biggest region, has the largest number of communities (around 2,500) that received rural roads between 2010 and 2014. The total length of the rural roads developed in Oromia during the period was about 13,000 $\mathrm{km}$, accounting for 64 percent of the total length in the nine regions.

A recent report (World Bank 2018b) shows that connectivity and accessibility of rural Ethiopians have substantially improved since 2010 . The average travel time to the nearest town decreased by nearly 30 minutes between 2010 and 2016. An additional 6 percent of rural Ethiopians were connected to rural roads during the same period, as the rural accessibility index (RAI) increased from 46 in 2010 to 52 in $2016 .{ }^{7}$ As a result, market accessibility improved except for some lagging regions. ${ }^{8}$

Although it appears that rural road development has taken place all around the country (see a map in Supplementary Materials), a comparison of baseline community characteristics illustrates that recent rural road development occurred in communities that were already better connected to begin with (Table A1 in Appendix). For example, the communities where rural roads were built or upgraded since 2010 were located closer to the nearest town (91 minutes) compared to the other communities (196 minutes). The length of un-upgraded rural roads was already longer in treated communities in 2010. In addition, treated communities were located in woredas with higher population density. On the other hand, treated communities (and the woredas they belong to) were not necessarily better-off in terms of poverty, educational level, and infrastructure and basic services. Nevertheless, this comparison clearly indicates the need to take account of the nonrandom placement in evaluating the results of rural road development (discussed more in Section 3). 


\section{Data}

The road network data in the Ethiopia road database were collected from different sources. Federal Road Network data were obtained from the Ethiopian Roads Authority, the main agency in the Road Sector Development Program (RSDP) and Growth and Transformation Plan (GTP); and district- and woreda-level road data were collected from the Regional Road Authorities. The collected information includes the year of new construction, upgrading, and rehabilitation, as well as the volume and distribution of the network in the country. It is important to note that the database includes rural roads that were motorable at the time of the national road inventory carried out in 2015-16. Rural roads in some parts of Oromia and Amhara regions were not covered due to missing bridges, as well as Somali region for security reasons.

In analyzing household-level impacts of the recent rural road development, this study primarily relies on the ESS. The ESS, part of the World Bank supported Living Standards Measurement Study-Integrated Surveys on Agriculture (LSMS-ISA), started as the Ethiopian Rural Socioeconomic Survey (ERSS) in 2012. A sample of about 3,470 households were interviewed in rural areas and re-interviewed in 2014 and 2016. Among the rural communities covered by the ESS, this study focuses on the communities where rural roads were built or upgraded (from unimproved barely motorable tracks to all-weather roads) between 2012 and 2014 (i.e., treated group) and the other communities that did not receive rural roads by 2016 (i.e., control group). This results in 172 communities, including 43 communities in Amhara, 34 communities in Oromia, 37 communities in SNNPR, 25 communities in Tigray, and 33 communities in the other regions.

The treatment indicator used for the econometric analysis in this study is a binary indicator on whether a rural road within the community's boundary was upgraded from an unpaved track to allweather road. The indicator does not consider road length. ${ }^{9}$ How to define households and areas affected by the rural road development is methodologically important. Given the nature of rural roads, this study considers that households in the communities in which all-weather rural roads 
were developed have been affected. ${ }^{10}$ Among the 172 communities analyzed for this study, 40 communities had URRAP or other types of rural roads developed between 2012 and 2014.

The main welfare outcome to be considered in this study is household consumption. The consumption aggregate in the ESS includes expenditures on and own-consumption of food (with a recall period of 7 days) and also includes spending on a selection of important nonfood items, including education. Health spending is not included in the aggregate to avoid that large expenses incurred following adverse health shocks would wrongly signal an increase in household welfare. This study expresses the consumption aggregate in the three waves of the ESS in 2016 prices. In addition, spatial adjustments are also made to account for differences in cost of living across regions. To convert the nominal consumption into a spatially adjusted real consumption, the consumer price index (CPI) is used to perform temporal adjustment (that is, convert all consumption values into 2016 prices) and the Fisher spatial price index is used for spatial adjustment. For the analysis of poverty, the poverty line is set to Birr 4,360 (in 2016 prices), which corresponded to the $40^{\text {th }}$ percentile of consumption expenditure distribution in 2016. Households that consume less than Birr 4,360 per adult equivalent per year (in 2016 prices) are considered as poor households in each wave. It is important to highlight that the official poverty lines in Ethiopia are developed based on a different survey. As a result, poverty estimates in this paper are not comparable with the official poverty statistics. Our purpose is instead to examine whether households in the lower income distribution benefited from the recent rural road developments.

According to the three waves of the ESS, household consumption has decreased between 2012 and 2016. Among the untreated group of communities, the average per adult-equivalent annual consumption (expressed in 2016 prices) decreased from 7,298 birr in 2012 to 5,605 birr in 2016 (Table 1). In tandem, the share of population in poverty has increased in those communities, reaching 43.7 percent in 2016. By contrast, mean consumption levels and poverty rates were relatively stable in treated communities during the period. 
This study employs an objective indicator of drought exposure. The 2015/16 drought is considered to be one of Ethiopia's worst droughts in the past five decades. About 10.2 million people in Ethiopia needed assistance. The drought was a result of rain failure during both the Meher (the main harvest) and Belg (spring harvest) seasons in 2015. In order to identify communities that were affected by the recent droughts, an objective measure is prepared. ${ }^{11}$ The normalized difference vegetation index (NDVI) is a commonly used measure of vegetation, and its deviation in the period of the droughts in 2015/16 from the long-term average - which is calculated as the z-scoreindicates the effect of the drought for agricultural production:

$$
Z_{j m}^{y}=\frac{\left(X_{j m}^{y}-\bar{X}_{j m}\right)}{S D\left(X_{j m}\right)}
$$

where $X_{j m}^{y}$ indicates the monthly value of NDVI in community $j$ in year $y ; \bar{X}_{j m}$ is the mean value over each month for the years 2000 to 2016 ; and $S D\left(X_{j m}\right)$ is the standard deviation over the period. ${ }^{12}$ Negative z-scores mean that the vegetation during the drought period was worse than the long-term average. Thus, households in the communities with z-scores below zero are identified as exposed to drought shock. We also use alternative thresholds of -0.5 and -1.0 , where the latter indicates the exposure to severe drought, accounting for 17.9 percent of households in the treated communities and 11.8 percent in the comparison group.

\section{Empirical strategy}

The primary approach of the econometric analysis in this study is a DID matching approach (Smith and Todd 2005), which combines DID and propensity score matching. In the impact analysis of rural road development, endogeneity problems arise when initial conditions influence project placement and the subsequent growth paths and prospects of the communities. While either DID or household fixed-effects-panel regression models can statistically control for time-invariant factors, either observed and unobserved in the data, it is still necessary to deal with time-varying factors to obtain unbiased estimates. This study estimates a DID model for households in the communities 
that are matched based on propensity scores; that is, the predicted probability of rural road upgrades happening in the communities (Rosenbaum and Rubin 1983; Imbens and Rubin 2016). The propensity score matching approach rests on the assumption of conditional independence; that is, the method is valid as long as the selection bias is conditional on the observed covariates. Unobservables affecting both the placement of rural roads and outcomes can still create a bias in estimating the impacts (discussed below).

The first step is to estimate propensity scores. The propensity score is estimated using a probit model at the community level, defined as follows:

$$
\begin{aligned}
& \operatorname{Pr}\left(\operatorname{Road}_{j}=1\right)= \\
& \quad F\left(\text { Connectivity }_{j}, \text { Demography }_{j}, \text { Infrastructure }_{j}, \text { Agroecological zone }_{j}\right)
\end{aligned}
$$

where the probability of community $j$ receiving rural roads between 2012 and 2014, $\operatorname{Pr}\left(\operatorname{Road}_{j}=1\right)$, depends on the community's prior characteristics about connectivity (such as length of all-weather roads in 2010 and the natural logarithm of travel time to the nearest town in 2010), demography and poverty (such as population density in 2007 , poverty rates in 2007 , and the share of adults with no education), and infrastructure (such as the share of households with public piped water and the share of households with electricity). We also add dummy indicators about agroecological zones to control for agricultural potentials. ${ }^{13}$ The estimation results of the propensity score model are presented in Table A2 in Appendix. Predicted probabilities of having rural road upgrades based on the results are the propensity scores. ${ }^{14}$

Then, kernel matching is performed to make communities in the treated and control groups comparable. In the kernel matching method, observations in the control group are assigned weights according to a kernel function of the predicted propensity scores (Heckman, Ichimura, and Todd 1997). ${ }^{15}$ We check covariate balancing to ensure the quality of matching. The comparison of mean values of covariates between the treated group and the control group in Table 2 shows that their differences were sufficiently reduced after matching. The mean difference in the length of all- 
weather roads between the treated and control groups is reduced by 99.5 percent. Other connectivity measures also show a profound reduction; for example, a 48 percent reduction for the log of travel time to the nearest town. Also, among the matched sample, the mean difference between the treated and control groups is not statistically significant in all the covariates. Alternative matching methods are also tested as a robustness check (in Section 5.3).

We then estimate the following standard DID model for households in the matched sample:

$$
y_{i j t}=\alpha+\beta_{1} \mathrm{ROAD}_{j}+\beta_{2} \mathrm{POST}_{t}+\beta_{3}(\mathrm{ROAD} \times \mathrm{POST})_{j t}+\beta_{4} X_{i j t}+\varepsilon_{i t}
$$

where $y_{i j t}$ is a vector of outcomes, such as the natural logarithm of per adult-equivalent annual consumption, for household $i$ in community $j$ at year $t$; $\operatorname{ROAD}_{j}$ is an indicator about the community's recipient status of rural road development; $\mathrm{POST}_{t}$ indicates the year when the outcome is measured (i.e., 2016); $X_{i t}$ includes various time-variant household characteristics (listed in Table S1 in Supplementary Materials); $\varepsilon_{i t}$ is an error term; and $\beta_{3}$ is the parameter that indicates the association between rural road development and the outcome $Y .{ }^{16}$ In estimating the models above, cluster robust standard errors are estimated to account for the clustering of households at the community level.

From a policy perspective, it is important to know whether households in remote communities and/or exposed to the recent droughts have benefited from recently developed rural roads. To explore such heterogeneity, we introduce interaction terms to Equation (3). In case of remoteness, which is expressed by a dummy indicator REMOTE ( 1 if the community is located beyond a threshold travel time (120 minutes, 180 minutes, or 240 minutes) from the nearest town; otherwise $0)$, the model is as follows: ${ }^{17}$

$$
\begin{aligned}
y_{i j t}=\alpha & +\beta_{1} \mathrm{ROAD}_{j}+\beta_{2} \mathrm{REMOTE}_{j}+\beta_{3} \mathrm{POST}_{t}+\beta_{4}\left(\mathrm{ROAD} \times \mathrm{REMOTE}_{j}+\right. \\
& \beta_{5}(\mathrm{ROAD} \times \mathrm{POST})_{j t}+\beta_{6}(\mathrm{REMOTE} \times \mathrm{POST})_{j t}+\beta_{7}(\mathrm{ROAD} \times \mathrm{REMOTE} \times \\
& \mathrm{POST})_{j t}+\beta_{8} X_{i j t}+\varepsilon_{i t}
\end{aligned}
$$


where $\beta_{5}$ indicates the degree of association between rural road development and outcome indicators for households in the communities that are located within a threshold travel time from the nearest towns (that is, REMOTE $=0)$ and $\left(\beta_{5}+\beta_{7}\right)$ indicates the association between rural roads and outcome indicators in communities that are located far from the nearest town (REMOTE $=1$ ). Heterogeneity in the rural road coefficient based on drought exposure is similarly examined based on Equation (4) with REMOTE replaced with a binary DROUGHT, which is 1 if the z-score of the NDVI is below a threshold $(0,-0.5$, or -1.0$)$ and otherwise 0 .

The DID matching method above cannot perfectly rule out endogeneity in estimating the effects of rural road development since unobserved factors may have critically affected the placement and outcome changes. Political capital is such a factor as reported in some previous studies in India (Lehne, Shapiro, and Eynde 2018) and Kenya (Burges et al. 2015). Communities with a strong relationship with local politicians might have been more likely to receive rural roads, and residents in the communities may also have received various supports that are not observed in our data. While we control for some assistance received by each household, such as the Productive Safety Net Program (PSNP) and the amount of transfers received, based on the ESS data, communitylevel political capital is not included there and thus creates room for endogeneity bias.

\section{Results}

\section{5-1. Welfare impacts}

We first confirm that rural road development is strongly and positively associated with household consumption changes between 2012 and 2016, according to the estimation results of the DID model in Equation (3). As reported in column 1 in Table 3, the estimation results suggest that the development of rural roads was associated with 18.6 percent higher (coefficient estimate 0.171 ) household consumption between 2012 and 2016 (or, given the consumption trends observed between 2012 and 2016, that rural road development was associated with a 18.6 percent lower decline in household consumption). ${ }^{18}$ This correlation estimate is larger than what Dercon et al. 
(2009) report for the impact of the access to all-weather roads on household consumption in rural Ethiopia: 16 percent increase between 1994 and 2004 or 1.5 percent annual increase.

Table 3 also summarizes the estimation results with different household welfare measures. The estimated association between rural roads and household welfare is robust against the choice of household consumption measures. Column 1 is the already reported benchmark based on the natural logarithm of consumption values (reported again for the sake of comparison). Estimating the coefficients as the changes in the level of consumption (using the non-log real consumption values as the outcome variable) in column 2 shows that rural roads increased annual household consumption by 1,199 birr [ $p=0.102]$. In addition, the estimation results with the log of nominal consumption show that the estimated linkage between rural road developments and household welfare changes are robust against the price adjustment (column 3). Focusing on only food consumption yields a higher estimate (a 21.5 percent increase between 2012 and 2016, column 4).

Recent rural road development also appears to have supported rural households from falling into or remaining in poverty. The results summarized in column 5 in Table 3 suggest that rural road development was associated with 15.6 percent lower change of households' falling into or remaining in poverty between 2012 and 2016 . This result suggests that the estimated association between the recent rural road developments and the household consumption increase is not driven by the benefits received by high-income households.

We also investigate the heterogeneity in the estimated association between rural road developments and consumption changes among rural households by their location characteristics. Column 1 in Table 4 reports coefficient estimates in Equation 4: $\beta 5$ in rows $\mathrm{C}$ and $\mathrm{E}$ and $(\beta 5+\beta 7)$ in rows $\mathrm{B}$ and D. The table shows only results based on 4-hour travel-time threshold for REMOTE and -1.0 zscore threshold for DROUGHT; the results based on other thresholds are reported in Table S2 in Supplementary Materials. The correlation estimate is larger in communities that are located very far away from towns (0.293 in row B) and/or severely hit by the droughts ( 0.400 in row D), though the coefficient estimates for the double interaction $(\beta 7)$ are not statistically significant in any of the 
specifications. It is also noted that the correlations are not clear when lower thresholds are applied to REMOTE (for example, 120 minutes and 180 minutes) and DROUGHT (for example, z-scores lower than zero or 0.5$)$.

An additional concern in assessing the role of rural roads in households' ability to cope with the drought is the effect of food aid. During the El Nino drought, humanitarian requirements skyrocketed and food aid was widely distributed. If food aid tended to be distributed to droughtaffected communities that could relatively easily be reached by trucks, the finding that the association between roads and welfare is stronger in drought-affected communities might simply reflect the role of food aid. Our analysis based on the LSMS data, which is reported in Table S3 in the Supplementary Materials, shows that this is unlikely to be the case: Households in better connected communities were not more likely to receive PSNP or food aid. Using a different dataset, World Bank (2020) also finds that households in more remote, poorly connected woredas (district) were more likely to receive food aid and PSNP, even though these communities may be more difficult to reach. Adding a dummy variable on food assistance at the household level as an additional control variable in the main regressions does not change any of the results (columns (4) and (8) in Table A3). The presence of food aid is thus unlikely to be driving the results.

\section{5-2. Agriculture and labor outcomes}

Rural farmers in remote areas appear to have sold more crops in connected communities. Column 2 in Table 4 reports the results for the share of harvested crops sold. While the result on all households in row A is not clear, households in very remote communities (more than 4 hours away from the nearest towns) that benefited from rural road development increased their marketorientation, with rural road development associated with sale a 15.4 percentage points increase in the share of crops sold. This result suggests that rural road developments influenced agricultural outcomes of farmers in very remote areas by providing better access to markets. The association between rural roads and crop sales is not observed in communities that are less than 4 hours away from the nearest towns (reported in Supplementary Materials). By contrast, rural roads were not 
associated with crop sales in communities hit by the droughts (row D), which is unsurprising given that agricultural production in those communities faltered during the drought.

Rural road development was also positively associated with the use of fertilizer in remote communities (column 3 in Table 4). As reported in the result on all households (row A), the overall association between rural road developments and fertilizer use marginal and statistically insignificant. In very remote communities though (more than 4 hour away from the nearest towns in row B), rural road development was associated with a higher share of farmers using fertilizers, consistent with findings of other studies that lower transport costs promote the use of modern inputs and technologies among farmers (Minten, Korn, \& Stifel, 2013; Damania et al., 2016; Aggarwal, 2018).

Some of the recently connected households started to engage in wage jobs. Columns 4 to 6 in Table 4 summarize the results of DID matching with the share of household members who engaged in wage jobs as the outcome. Column 4 reports the results for all household members, whereas column 5 and column 6 summarize the results for women and the youth, respectively. The association between rural road developments and wage employment is not clear when all household members are analyzed (row A). The correlations were particularly strong among women and youth in remote areas. As summarized in column 5 in Table 4, the development of rural roads in remote areas (travel time more than 240 minutes) was associated with the increase in the share of female members with wage jobs by 4.8 percentage points. The chance of engaging with wage jobs among the youth was 4.6 percentage points higher (Row A in column 6), while the estimate is even larger in remote communities (14.1 points in row B). Given the very small share of wage workers in the sample (Table 1), this association is by no means marginal. The increase in wageemployment in the newly-connected remote communities is mainly due to an increase in casual labor in construction, both for women and youth. It is possible that this included construction and maintenance works on the rural roads themselves, as URRAP prioritized the use of local labor in upgrading and maintaining the roads. 


\section{5-3. Robustness check}

As already discussed in Section 5.1, the estimated association between the recent rural road developments and household consumption gains was robust against different specification in the DID-matching models (Table A3) and different welfare measures (Table 3). The estimated effects above do not substantially change when other matching methods are applied. Table A4 in the Appendix summarizes the results based on kernel matching with different band widths and one-toone nearest neighbor matching. Column 1 reports the benchmark based on kernel matching with a bandwidth of 0.06: the estimated coefficient for the interaction term $($ ROAD $\times$ POST $)$ is 0.171 . By changing the bandwidth to 0.03 (column 2) and 0.12 (column 3) does not substantially alter the coefficient estimate ( 0.198 and 0.169 , respectively). Applying a nearest neighbor matching yields larger estimates on household consumption than those based on kernel matching. Regardless of setting caliper (column 5) or not (column 4), the results demonstrate that rural roads increased household consumption by more than 20 percent between 2012 and 2016 .

A concern in this study is that we focus on short-term effects of rural road developments as only the rural roads developed between 2012 and 2014 are considered. Including rural roads that were developed between 2010 and 2012 is an alternative approach to capture medium-term effects. This increases the number of matched households to 4,030 in 194 communities. However, as the baseline household consumption measured in 2012 ESS data had already captured the short-term impact of the 2010-12 rural roads, the association between rural road development and household consumption could be underestimated. In fact, the estimation results of a new matching DID model on the larger sample yield a slightly lower coefficient estimate $(0.161)$ than our preferred estimate $(0.171) .^{21}$ 


\section{Conclusion}

This study assesses the linkage between recently developed rural roads and household welfare, resilience, and economic activities. Two panel data sets, one of rural households in Ethiopia and one on transport networks make it possible to relate the development of rural roads to welfare changes across space and over time. The study period between 2010 and 2016 overlaps with the implementation of a large-scale rural road development program(URRAP) as well as a historically severe drought, which allows us to analyze the contribution of rural roads to resilience against covariate shocks.

The study finds that rural road development was associated with significantly better household welfare outcomes. Since overall household consumption decreased during the study period, this result should be interpreted as rural roads limiting the consumption losses of households in the communities where rural roads were developed. We find suggestive evidence that rural road development played a more important role in drought-affected communities, which is in line with several recent findings on the role of connectivity in mitigating the impacts of severe covariate shocks.

While the association between road development and household welfare did not differ significantly across baseline levels of remoteness, certain results suggest that households in communities that were very remote to begin with benefited most. In remote communities, rural road development was associated with an increased market orientation of farmers, as reflected in a higher share of harvested crops sold. Use of agricultural inputs also increased in newly connected remote communities. Importantly, benefits of increased connectivity were not driven by better-off households, as rural road development was associated with 15.6 percent lower chance of households' being poor.

In addition, rural road development was associated with an increase in wage employment in remote communities, especially among women and youth. This may however have been directly related to 
the rural roads works, as the type of employment that increased was casual wage labor on construction works.

The findings above highlight that rural road development contributed significantly to the welfare of rural households, and helped to increase households' resilience to adverse weather shocks. Despite the positive findings observed in this paper, the implementation of the URRAP has been slowing down due to, among other factors, the lack of financial resources. In light of the results, it will be important to connect the remaining kebeles, particularly in remote areas, to accelerate poverty reduction and enhance the resilience of rural populations against shocks. 


\section{Notes}

1. Moreover, it is often hard to keep track of the rural road development across time and space if the program covers the entire area of a country. It is becoming common to rely on satellite imageries in economic studies (Donaldson and Storeygard 2017), though rural roads - which are community roads - and their changes in quality are hard to identify with such an approach because of their narrow and short paths.

2. There are some other studies investigating the impacts of rural road access in the developing world. Jalan and Ravallion (2002) find positive impacts of rural roads on consumption growth in China. A study of Vietnam by $\mathrm{Mu}$ and van de Walle (2011) found positive impacts of rural road rehabilitation on local market development. Damania et al. (2016) found that transport cost reduction encourages farmers to adopt modern technologies in Nigeria.

3. Aggarwal (2018) finds lower prices, increased availability of non-local goods, increased use of agricultural technologies, and increased school enrollment among younger children in districts where the PMGSY program was implemented. Another study of the PMGSY by Shamdasani (2016) finds crop diversification among farmers in connected villages.

4. A 'kebele' is a subdivision of woreda and the smallest administrative unit in Ethiopia. It is similar to a ward, a neighborhood, or parish in other countries. We refer to it as community in the remaining part of this paper. Woreda is an administrative unit of one level higher than kebele.

5. In addition to the URRAP, the Productive Safety Net Program (PSNP) - a large social protection project providing transfers to food insecure areas - also has a component of rural road construction. Those roads are generally earth roads for very low traffic levels, connecting watersheds to kebeles and other service centers. Some feeder roads were constructed under the Agricultural Growth Program (AGP), which is a program focusing on increasing sustainable agriculture growth in potentially rich, but underdeveloped woredas of the country. See World Bank (2018) for a comprehensive review of Ethiopia's rural road programs.

6. The identification of URRAP and other rural roads is based on the Ethiopia road database. The total length of those roads does not necessarily correspond to the official records. Somali region and a part of Amhara and Oromia regions are not included for this study due to data availability.

7. The RAI was measured by the share of population in each community who lives within $2 \mathrm{~km}$ from any all-weather road. The calculated RAI differs from World Bank (2016) due to the definitions of all-weather roads, as well as the coverages of roads and geographic areas. 
8. Market accessibility index (MAI) was calculated for each community as the sum of the population in the other communities within a certain travel time, as in Donaldson and Hornbeck (2016) and Berge, Blankespoor, and Selod (2016).

9. Development of non-rural roads, such as regional corridors, is not considered as the treatment. Iimi et al. (2018) is an example that analyzes the impacts of road access by distinguishing rural roads and regional corridors in Ethiopia.

10. No spatial spillover is a key assumption for the identification of the impacts of rural roads (stable unit treatment value assumption, or SUTVA).

11. In the ESS data, a lot of households reported that they had been affected by drought during the last 12 months. In the study area, 29 percent of the households were affected by drought in 2015/16. However, such measure of drought exposure reported by households - and even by communities - can be susceptible to measurement errors, and the errors can be correlated with the respondents' income levels if lower-income households are more likely to overstate the drought impact and/or higher-income households tend to understate the impact.

12. NDVI was calculated based on the MODIS Terra satellite data.

13. Agro-ecological zones include tropic-warm/arid zone, tropic-warm/semiarid zone, tropicwarm/subhumid zone, tropic-cool/subhumid zone, tropic-cool/semiarid zone, and tropiccool/humid zone (HarvestChoice and IFPRI 2016).

14. Panel (A) of Figure A1 in the Appendix shows the distribution of propensity scores for both treated and control groups. It is visually clear that communities in the treated group are concentrated in higher scores, whereas many communities in the control group are in lower scores. Panel (B) of Figure A1 shows propensity scores for the matched households.

15. The Epanechnikov kernel function with a bandwidth of 0.06 is specified for the analysis. Robustness against the choice of bandwidth is examined in Section 5.3.

16. Among the covariates are the controls for assistance, including the dummy indicator about whether the household received a cash transfer from the PSNP during the last 12 months; the dummy indicator whether any member of the household participated in the PSNP labor work during the last 12 months; and the natural logarithm of the amount of transfer received by the household during the last 12 months. All these variables are based on self-reports in the ESS.

17. Travel time to the nearest town is calculated by assuming different travel speeds for various road types in the Ethiopia road database. Foot-based speed is used for the path from the centroid of the community to the nearest road. 
18. The results based on different sets of specifications are reported in Table A3 in Appendix. The coefficient estimate for the interaction term ( $\beta_{3}$ in Equation 3 ) between the dummy variable about the rural road indicator (ROAD) and the year dummy (POST) indicates the association between rural road development and household consumption changes between 2012 and 2016. The coefficient estimate in the baseline result with no control variable in column $1(0.135)$ indicates that the mean consumption in the treated communities is 14.5 percent higher than that in the control communities. The coefficient estimate remains at the similar level when additional control variables are added, such as household characteristics (column 2), drought shocks (column 3), and assistance (column 4). Compared to the results based on the unmatched sample above, the results for the matched sample show slightly stronger association.

19. Results are available upon request.

20. A recent case study of Ethiopia road development by Iimi et al. (2018) finds that farmers' access to input markets (including fertilizers) was improved mainly by main corridor improvement instead of feeder road development.

21. Results are available upon request. 


\section{References}

Aggarwal, S. (2018). Do rural roa ds crea te pa thways out of poverty? Evidence from India. Journal of Development Economics, 133,375-395.

Asher, S., \& Novosad,P. (2019). Rural roads and local economic development. American Economic Review, forthcoming.

Berg, C. N., Blankespoor, B. \& Selod, H. (2016). Roads and rural development in Sub-Saharan Africa. World Bank Policy Research Working Paper 7729.

Berg, C. N., Deichmann, U., Liu, Y. \& Selod, H. (2017). Transport policies and development. Journal of Development Studies, 53(4), 465-480.

Blimpo, M. P., Harding, R. \& Wantchekon, L. (2013). Public investment in rural infra structure: Some political economy consideration. Journal of African Economics, 22(AEKS Supplement 2), 5783.

Burgess, R., Jedwab, R., Miguel, E., Morjaria, A., \& Miquel, G. P. I. (2015). The value of democracy: Evidence from roa d building in Kenya.American Economic Review, 105(6), 1817-51.

Carter, M. R., Little, P. D., Mogues, T., \& Nega tu, W. (2007). Poverty traps a nd natural disa sters in Ethiopia and Honduras. World Development, 35(5), 835-856.

Damania, R., Berg, C., Russ, J., Barra, A.F., Nash, J., \& Ali, R. (2016). Agricultural technology choice and transport. American Journal of Agricultural Economics, 99(1), 265-284.

Dercon, S., Hoddinott, J., \& Woldehanna, T. (2005). Shocks and consumption in 15 Ethiopian villages, 1994-2004. Journal of African Economies, 14(4), 559-585.

Dercon, S., Gilliga n, D. O., Hoddinott, J., \& Woldehanna, T. (2009). The impact of agricultural extension and roads on poverty and consumption growth in fifteen Ethiopian villages. American Journal of Agricultural Economics, 91(4), 1007-1021.

Dercon, S., \& Porter, C. (2014). Live Aid revisited: Long-term impacts of the 1984 Ethiopian famine on children. Journal of the European Economic Association, 12(4),927-948.

Dona ldson, D., \& Hornbeck, R. (2016). Ra ilroa ds and American economic growth: A 'Market Access' approach. Quarterly Journal of Economics, 131(2), 799-858.

Donaldson, D., \& Storeygard, A. (2017). The view from above: Applications of sa tellite data in economics. Journal of Economic Perspectives, 30(4), 171-198.

Fuje, H. (2017). Recent welfare dynamics and drought in Ethiopia. Unpublished manuscript.

Ga o, J., \& Mills, B.F. (2018). Wea ther shocks, coping strategies, and consumption dynamics in rural Ethiopia. World Development, 101,268-283.

Hine, J., Abedin, M., Stevens, R., Airey, T., \& Anderson, T. (2016). Does the extension of the rural road network have a positive impact on poverty reduction and resilience for the rural areas served? If so how, and if not why not? A systematic review. London: EPPI-Centre, Social Science Research Unit, UCL Institute of Education, University College London.

HarvestChoice and IFPRI (InternationalFood Policy Resea rch Institute). (2016). CELL5M: A Multidisciplinary Geospatial Database for Africa South of the Sahara. Harvard Dataverse, V4.

Heckman, J., Ichimura, H., \& Todd, P. (1997). Matching a s a econometric evaluation estimator: evidence from evaluating a job training program. Review of Economic Studies, 64(4), 605-654. 
Hill, R. \& Fuje, H. (2018). What is the impact of drought on prices? Evidence from Ethiopia. Paper presented at CSAE Conference, University of Oxford.

Hirvonen, K., Sohnesen, T., and Bundervoet, T. (2017). Impact of Ethiopia 's 2015 drought on child undernutrition. IFPRI Strategy Support Program Working Pa per 114.

Iimi, A., Mengesha, H., Markland, J., Asrat, Y., \& Kassahun, K. (2018). Heterogenous impacts of main and feeder road improvements: Evidence from Ethiopia. World Bank Policy Resea rch Working Paper 8548 .

Imbens, G. W., \& Rubin, D.B. (2016). Causal Inferencefor Statistics, Social, and Biomedical Sciences: An Introduction. New York: Cambridge University Press.

Jalan, J., \& Ravallion, M. (2002). Geographic poverty traps? A micro model of consumption growth in rural China. Journal of Applied Econometrics, 17,329-346.

Khandker, S. R., Bakht, Z., \& Koolwal, G.B. (2009). The poverty impact of rural roads: Evidence from Bangladesh.Economic Development and Cultural Change, 57(4), 685-722.

Lehne, J., Shapiro, J. N., \& Oliver, V.E. (2018). Building connections: Political corruption and road construction in India. Journal of Development Economics, 131, 62-78.

Little, P. D., M. P. Stone, T. Mogues, A. P. Castro, and W. Negatu. 2006." "Moving in Place': Drought and Poverty Dynamics in South Wollo, Ethiopia." The Journal of Development Studies, 42 (2): $200-225$.

Lokshin, M., \& Yemtsov, R. (2005). Ha s rural infrastructure rehabilita tion in Georgia helped the poor? The World Bank Economic Review, 19(2), 311-333.

Minten, B., Korn, B., \& Stifel, D. (2013). The last mile(s) in modern input distribution: Pricing, profita bility, and a doption. Agricultural Economics, 44, 629-646.

Mu, R., \& van de Walle, D. (2011). Rural roads and localmarket development in Vietnam. Journal of Development Studies, 47(5), 709-734.

Rosenbaum, P.R., \& Rubin, D.B. (1983). The centralrole of the propensity score in observational studies for causaleffects. Biometrika, 70(1),41-55.

Shamdasani, Y. (2016). Rural road infrastructure and agricultural production: Evidence from India. Unpublished manuscript.

Smith, J. A., \& Todd, P.E. (2005). Does matching overcome LaLonde's critique of nonexperimental estima tors? Journal of Econometrics, 125(1-2), 305-353.

Stifel, D., Minten, B., \& Koru, B. (2016). Economic benefits of rural feeder roads: Evidence from Ethiopia. The Journal of Development Studies, 52(9), 1335-1356.

Thiede, B. C. (2014). Ra infall shocks and within-community wea lth inequality: Evidence from rural Ethiopia. World Development, 64, 181-193.

van de Walle, D. (2009). Impact evaluation of rural roa d projects. Journal of Development Effectiveness, 1(1), 15-36.

van de Walle, D. (2002). Choosing rural road investments to help reduce poverty. World Development, $30(4), 575-589$.

World Bank.(2016). Measuring rural access: Using new technologies. Washington, D.C.: World Bank. 
World Bank. (2018a). Poverty and shared prosperity 2018: Piercing together the poverty puzzle. Washington, D.C.: World Bank.

World Bank.(2018b). Review of the Ethiopian rural roads program: Study report. Wa shington, D.C.: World Bank.

World Bank.(2020).Ethiopia Poverty Assessment. Wa shington, D.C.: The World Bank. 


\section{Tables}

Table 1. Outcome and key variables 2012-2016 (prior to adjustment)

\begin{tabular}{|c|c|c|c|c|}
\hline & \multicolumn{2}{|c|}{ Treated } & \multicolumn{2}{|c|}{ Control } \\
\hline & 2012 & 2016 & 2012 & 2016 \\
\hline $\begin{array}{l}\text { More than } 120 \text { minutes away from the nearest town }(1=\text { yes; } 0=\text { no }) \\
\text { in } 2012\end{array}$ & 0.211 & 0.211 & 0.410 & 0.410 \\
\hline $\begin{array}{l}\text { More than } 180 \text { minutes away from the nearest town }(1=\text { yes; } 0=\text { no }) \\
\text { in } 2012\end{array}$ & 0.134 & 0.134 & 0.270 & 0.270 \\
\hline $\begin{array}{l}\text { More than } 240 \text { minutes away from the nearest town }(1=\text { yes; } 0=\text { no }) \\
\text { in } 2012\end{array}$ & 0.080 & 0.080 & 0.210 & 0.210 \\
\hline $\begin{array}{l}\text { Exposed to droughts between } 2014 \text { and } 2016(1 \text { if z-score of NDVI }< \\
0 ; \text { otherwise } 0)\end{array}$ & 0.627 & 0.627 & 0.590 & 0.590 \\
\hline $\begin{array}{l}\text { Exposed to droughts between } 2014 \text { and } 2016(1 \text { if } z \text {-score of NDVI }< \\
-0.5 ; \text { otherwise } 0)\end{array}$ & 0.432 & 0.432 & 0.347 & 0.347 \\
\hline $\begin{array}{l}\text { Exposed to droughts between } 2014 \text { and } 2016(1 \text { if z-score of NDVI }< \\
-1.0 ; \text { otherwise } 0)\end{array}$ & 0.179 & 0.179 & 0.118 & 0.118 \\
\hline Per adult equivalent annual consumption (2016 Birr) & 6755 & 6193 & 7298 & 5605 \\
\hline Poor $(1$ if consumption $<4360$; otherwise 0$)$ & 0.367 & 0.369 & 0.334 & 0.437 \\
\hline Whether the household sold any crop this season $(1=$ yes; $0=$ no $)$ & 0.398 & 0.655 & 0.574 & 0.762 \\
\hline $\begin{array}{l}\text { Share of crops sold by the households among the harvested crops } \\
\text { this season }(\%)\end{array}$ & 3.249 & 10.66 & 10.52 & 16.93 \\
\hline Fertilizer used during the last 12 months $(1=$ yes; $0=$ no $)$ & 0.771 & 0.831 & 0.714 & 0.758 \\
\hline $\begin{array}{l}\text { Share of household members engaged in wage job during the last } 12 \\
\text { months }(\%)\end{array}$ & 6.349 & 5.113 & 6.066 & 4.396 \\
\hline $\begin{array}{l}\text { Share of female household members engaged in wage job during the } \\
\text { last } 12 \text { months }(\%)\end{array}$ & 2.010 & 2.136 & 2.768 & 1.757 \\
\hline $\begin{array}{l}\text { Share of young household members engaged in wage job during the } \\
\text { last } 12 \text { months }(\%)\end{array}$ & 3.513 & 2.201 & 6.378 & 1.685 \\
\hline
\end{tabular}




\section{Table 2. Balancing of covariates before and after matching}

\begin{tabular}{|c|c|c|c|c|c|c|c|c|c|}
\hline & \multicolumn{3}{|c|}{ Unmatched } & \multicolumn{3}{|c|}{ Matched } & \multirow{2}{*}{$\begin{array}{c}\% \mid \text { bias } \mid \\
\text { reduction }\end{array}$} & \multicolumn{2}{|c|}{ t-test } \\
\hline & Treated & Control & $\%$ bias & Treated & Control & $\%$ bias & & t-value & $\mathrm{p}>|\mathrm{t}|$ \\
\hline Length of all-weather roads (km) & 9.738 & 4.416 & 120.5 & 8.896 & 8.838 & 0.7 & 99.5 & 0.04 & 0.971 \\
\hline $\ln$ (Travel time to town in minutes) & 3.893 & 4.381 & -11.1 & 3.982 & 3.764 & 5.8 & 48.0 & 1.09 & 0.277 \\
\hline $\ln (\mathrm{MAI})$ & 12.37 & 11.76 & 5.2 & 12.26 & 12.25 & 0.1 & 98.4 & 0.02 & 0.988 \\
\hline $\ln$ (Length of all-weather roads in woreda) & 4.758 & 4.281 & 11.1 & 4.667 & 4.658 & 0.2 & 98.3 & 0.06 & 0.956 \\
\hline RAI at woreda & 43.11 & 40.34 & 6.9 & 42.91 & 46.77 & -8.3 & -20.2 & -0.86 & 0.392 \\
\hline $\ln$ (Population density of woreda) & 4.774 & 4.707 & 1.4 & 4.709 & 4.703 & 0.1 & 91.0 & 0.03 & 0.977 \\
\hline Poverty rate at woreda $(\%)$ & 36.69 & 30.97 & 18.5 & 36.77 & 32.17 & 14.3 & 22.6 & 1.39 & 0.167 \\
\hline Share of no education $(\%)$ & 74.31 & 73.01 & 1.8 & 74.00 & 72.55 & 2.0 & -12.2 & 0.41 & 0.683 \\
\hline Share of public tap (\%) & 21.09 & 15.31 & 37.8 & 21.20 & 15.88 & 33.5 & 11.3 & 1.12 & 0.266 \\
\hline Electricity $(\%)$ & 9.843 & 7.312 & 34.6 & 7.612 & 8.000 & -4.9 & 86.0 & -0.07 & 0.943 \\
\hline Tropic-warm $(\%)$ & 6.437 & 26.03 & -75.3 & 6.562 & 13.17 & -50.2 & 33.3 & -1.24 & 0.218 \\
\hline Tropic-cool/sub-humid zone (\%) & 40.92 & 34.43 & 18.8 & 41.99 & 39.39 & 6.6 & 65.0 & 0.23 & 0.818 \\
\hline Tropic-cool / semi-arid zone (\%) & 50.11 & 25.89 & 93.5 & 48.82 & 42.20 & 15.7 & 83.2 & 0.54 & 0.592 \\
\hline Tropic-cool/ humid zone (\%) & 2.529 & 13.65 & -81.5 & 2.625 & 5.235 & -49.9 & 38.8 & -0.85 & 0.398 \\
\hline
\end{tabular}

Note: The unit of analysis is rural households in the ESS. Matched sample was created by kernel matching method based on propensity scores (estimated based on the propensity score model in Table A2). Standard errors in t-test were clustered at the community-level.

Table 3. Estimation results on household welfare

\begin{tabular}{|c|c|c|c|c|c|}
\hline & $\begin{array}{l}\text { Log of real } \\
\text { consumption } \\
\text { (1) }\end{array}$ & $\begin{array}{c}\text { Real } \\
\text { consumption } \\
(2)\end{array}$ & $\begin{array}{l}\text { Log of nominal } \\
\text { consumption } \\
\text { (3) }\end{array}$ & $\begin{array}{l}\text { Log of real food } \\
\text { consumption } \\
\text { (4) }\end{array}$ & $\begin{array}{c}\text { Poverty } \\
\text { (5) }\end{array}$ \\
\hline \multirow[t]{2}{*}{$\beta 1: R O A D$} & -0.066 & -541.8 & -0.086 & -0.073 & 0.064 \\
\hline & $(0.076)$ & $(608.1)$ & $(0.081)$ & $(0.086)$ & $(0.055)$ \\
\hline \multirow[t]{2}{*}{$\beta 2: P O S T$} & $-0.197^{* * *}$ & $-1981^{* * *}$ & 0.071 & $-0.272^{* * *}$ & $0.185^{* * *}$ \\
\hline & $(0.075)$ & (548.4) & $(0.074)$ & $(0.083)$ & $(0.055)$ \\
\hline \multirow[t]{2}{*}{$\beta 3: R O A D \times P O S T$} & $0.171^{*}$ & 1199 & $0.199^{* * *}$ & $0.195^{*}$ & $-0.156^{* *}$ \\
\hline & $(0.099)$ & $(731)$ & $(0.095)$ & $(0.105)$ & $(0.074)$ \\
\hline Hous ehold characteristics & Yes & Yes & Yes & Yes & Yes \\
\hline Observations (clusters) & $3319(164)$ & $3341(164)$ & $3341(164)$ & $3391(163)$ & $3377(164)$ \\
\hline
\end{tabular}

Note: The unit of observations is the matched sample of rural hous eholds in the 2012 and 2016 ESS. The DID model in Equations 2 was estimated with the natural logarithm of per adult equivalent hous ehold annual consumption (column 1) and other welfare measures (columns 2 to 5) as the outcome variable. The coefficient estimate for $(\mathrm{ROAD} \times \mathrm{POST})$ indicates the association between rural road development and the outcome. Household characteristics are controlled (see Table $\mathrm{S} 1$ in the Supplementary Materials for the descriptions of the variables). Cluster robust standard errors in parentheses. ${ }^{*},{ }^{* *}$, and ${ }^{* * *}$ indicate significance level of estimated impacts at $10 \%, 5 \%$, and $1 \%$ levels. 
Table 4. Summary of results on household welfare and economic indicators

\begin{tabular}{|c|c|c|c|c|c|c|}
\hline & \multirow[b]{2}{*}{$\begin{array}{c}\text { Log } \\
\text { consumption } \\
\text { (1) }\end{array}$} & \multirow[b]{2}{*}{$\begin{array}{l}\text { Share of } \\
\text { crop sold } \\
\text { (2) }\end{array}$} & \multirow[b]{2}{*}{$\begin{array}{c}\text { Fertilizer } \\
\text { use } \\
(3)\end{array}$} & \multicolumn{3}{|c|}{ Wage jobs } \\
\hline & & & & $\begin{array}{c}\text { All } \\
\text { members } \\
(4)\end{array}$ & $\begin{array}{c}\text { Female } \\
\text { members } \\
(5)\end{array}$ & $\begin{array}{l}\text { Young } \\
\text { members } \\
\text { (6) }\end{array}$ \\
\hline (A) All hous eholds & $\begin{array}{c}0.171^{*} \\
(0.099)\end{array}$ & $\begin{array}{c}0.006 \\
(0.022)\end{array}$ & $\begin{array}{c}0.008 \\
(0.036)\end{array}$ & $\begin{array}{c}0.009 \\
(0.016)\end{array}$ & $\begin{array}{c}0.006 \\
(0.010)\end{array}$ & $\begin{array}{l}0.046^{* *} \\
(0.023)\end{array}$ \\
\hline $\begin{array}{l}\text { By travel time to town } \\
\text { (B) } R E M O T E=1 \text { (travel time } \geq 240 \text { minutes) }\end{array}$ & $\begin{array}{l}0.293^{* * *} \\
(0.054)\end{array}$ & $\begin{array}{l}0.154^{* * *} \\
(0.054)\end{array}$ & $\begin{array}{l}0.357^{* * *} \\
(0.085)\end{array}$ & $\begin{array}{c}0.018 \\
(0.054)\end{array}$ & $\begin{array}{l}0.048^{*} \\
(0.025)\end{array}$ & $\begin{array}{l}0.141^{* *} \\
(0.070)\end{array}$ \\
\hline (C) $R E M O T E=0$ (travel time $<240$ minutes $)$ & $\begin{array}{l}0.172^{*} \\
(0.101)\end{array}$ & $\begin{array}{l}-0.006 \\
(0.022)\end{array}$ & $\begin{array}{l}-0.019 \\
(0.035)\end{array}$ & $\begin{array}{c}0.008 \\
(0.017)\end{array}$ & $\begin{array}{c}0.003 \\
(0.010)\end{array}$ & $\begin{array}{l}0.038 \\
(0.023)\end{array}$ \\
\hline $\begin{array}{l}\text { By drought exposure } \\
\text { (D) } D R O U G H T=1(\text { vegetation } \mathrm{z} \text {-score } \leq-1.0)\end{array}$ & $\begin{array}{l}0.400^{*} \\
(0.227)\end{array}$ & $\begin{array}{l}-0.046 \\
(0.039)\end{array}$ & $\begin{array}{l}0.151^{* *} \\
(0.069)\end{array}$ & $\begin{array}{l}0.047^{* *} \\
(0.024)\end{array}$ & $\begin{array}{c}-0.006 \\
(0.012)\end{array}$ & $\begin{array}{c}0.092^{*} \\
(0.049)\end{array}$ \\
\hline (E) $D R O U G H T=0($ vegetation $\mathrm{z}$-score $>-1.0)$ & $\begin{array}{c}0.132 \\
(0.103)\end{array}$ & $\begin{array}{c}0.014 \\
(0.025)\end{array}$ & $\begin{array}{l}-0.022 \\
(0.066)\end{array}$ & $\begin{array}{l}-0.001 \\
(0.018)\end{array}$ & $\begin{array}{c}0.007 \\
(0.011)\end{array}$ & $\begin{array}{c}0.031 \\
(0.024)\end{array}$ \\
\hline
\end{tabular}

Note: The unit of observations is the matched sample of rural hous eholds in the 2012 and 2016 ESS. The DID models in Equations 2 and 3 were estimated with different outcome variables in the columns. The coefficient estimates for $(\beta 5+\beta 7)$ are reported, which indicates the association between rural road development and the outcome among households in remote communities (row B) or households in communities hit by the drought (row D). Household characteristics are controlled (see Supplementary Materials for the descriptions of the variables). Cluster robust standard errors in parentheses. ${ }^{* * *}$, and ${ }^{* * *}$ indicate significance levelof estimated impacts at $10 \%, 5 \%$, and $1 \%$ levels. Tables S2, S4, and S5 in the Supplementary Materials report detailed results. 


\section{Appendix A.}

Table A1. Baseline community characteristics with and without rural road developments

\begin{tabular}{|c|c|c|c|c|}
\hline & \multicolumn{2}{|c|}{ Rural road received } & \multirow[b]{2}{*}{ Difference } & \multirow[b]{2}{*}{$\%$} \\
\hline & Yes & No & & \\
\hline Length of all-weather road $2010(\mathrm{~km})$ & 5.721 & 2.298 & 2.973 & 129.4 \\
\hline Travel time to town 2010 (minutes) & 91.35 & 196.2 & -104.8 & -53.6 \\
\hline Log(Market Accessibility Index) 2010 & 12.44 & 11.41 & 1.028 & 9.0 \\
\hline Length of all-weather road 2010 at woreda $(\mathrm{km})$ & 116.2 & 98.93 & 17.27 & 17.2 \\
\hline Rural Accessibility Index 2010 at woreda (\%) & 50.37 & 39.15 & 11.22 & 46.1 \\
\hline Population density 2010 at woreda (per km2) & 202.6 & 160.2 & 42.40 & 26.9 \\
\hline Poverty rate 2011 at woreda (\%) & 30.57 & 30.61 & -0.040 & -0.0 \\
\hline Average age 2007 & 21.24 & 21.24 & 0.000 & 0.0 \\
\hline Share of no education $2007(\%)$ & 70.39 & 73.58 & -3.190 & -4.3 \\
\hline Share of public tap $2007(\%)$ & 16.24 & 13.09 & 3.150 & 23.7 \\
\hline Share of no toilet $2007(\%)$ & 73.34 & 75.95 & -2.610 & -3.6 \\
\hline Share of electricity for lighting 2007 (\%) & 2.151 & 2.369 & -0.218 & -8.3 \\
\hline Agro-ecological zone: Tropic-warm/semiarid at woreda (\%) & 2.112 & 7.361 & -5.249 & -71.6 \\
\hline Agro-ecological zone: Tropic-warm/subhumid at woreda (\%) & 4.240 & 9.456 & -5.216 & -55.8 \\
\hline Agro-ecological zone: Tropic-cool/subhumid at woreda $(\%)$ & 55.97 & 46.66 & 9.310 & 20.0 \\
\hline Agro-ecological zone: Tropic-cool/semiarid at woreda (\%) & 19.52 & 20.73 & -1.210 & -5.8 \\
\hline Agro-ecological zone: Tropic-cool/humid at woreda $(\%)$ & 18.16 & 15.79 & 2.370 & 15.2 \\
\hline
\end{tabular}

Note: The unit of observations is rural communities (kebeles) in the Ethiopia road database.

\section{Table A2. Estimation results of propensity score model}

\begin{tabular}{|c|c|}
\hline & $\begin{array}{l}\text { Whether rural } \\
\text { roads received }\end{array}$ \\
\hline Length of all-weather road 2010 & $\begin{array}{c}0.083^{* * *} \\
(0.009)\end{array}$ \\
\hline $\ln$ (Travel time to town 2010) & $\begin{array}{c}-0.234^{* * * *} \\
(0.026)\end{array}$ \\
\hline Road $\times \ln ($ Travel time to town $)$ & $\begin{array}{c}0.007^{*} \\
(0.003)\end{array}$ \\
\hline $\ln ($ Market Accessibility Index 2010) & $\begin{array}{c}-0.040^{* * *} \\
(0.008)\end{array}$ \\
\hline $\ln ($ Length of all-weather road 2010 in Woreda) & $\begin{array}{c}2.260^{* * * *} \\
(0.384)\end{array}$ \\
\hline Rural Accessibility Index 2010 in Woreda & $\begin{array}{l}1.030^{* * *} \\
(0.122)\end{array}$ \\
\hline $\ln$ (Population density 2007 in Woreda) & $\begin{array}{c}-0.133^{* * *} \\
(0.030)\end{array}$ \\
\hline Poverty rate 2011 in Woreda & $\begin{array}{c}0224^{*} \\
(0.124)\end{array}$ \\
\hline Share of adults with no education & $\begin{array}{l}-0.105 \\
(0.090)\end{array}$ \\
\hline Share of households with public piped water & $\begin{array}{l}-0.039 \\
(0.069)\end{array}$ \\
\hline Electricity & $\begin{array}{c}-0.283^{* * *} \\
(0069)\end{array}$ \\
\hline Tropic-cool/sub-humid zone & $\begin{array}{c}0.990^{* * *} \\
(0.077)\end{array}$ \\
\hline Tropic-cool/semi-arid zone & $\begin{array}{l}1.120^{* * * *} \\
(0.079)\end{array}$ \\
\hline Tropic-cool/humid zone & $\begin{array}{l}0.330^{* * *} \\
(0.091)\end{array}$ \\
\hline Constant & $\begin{array}{c}-2.908^{* * *} \\
(0.187) \\
\end{array}$ \\
\hline $\begin{array}{l}\text { Prob }>\text { chi } 2 \\
\text { Obs. }\end{array}$ & $\begin{array}{r}0.000 \\
9852 \\
\end{array}$ \\
\hline
\end{tabular}
9852

Note: The unit of observations is rural communities (kebeles) in the Ethiopia road database. The probit model includes the binary indicator about whether the community received rural roads between 2012 and 2014 as the dependent variable. Standard errors in parentheses. ${ }^{* * *}$, and ${ }^{* * *}$ indicate significance level of estimated impacts at $10 \%, 5 \%$, and $1 \%$ levels. 
Table A3. Estimation results on household consumption

\begin{tabular}{|c|c|c|c|c|c|c|c|c|}
\hline & \multicolumn{4}{|c|}{ Unmatched } & \multicolumn{4}{|c|}{ Matched } \\
\hline & (1) & $(2)$ & $(3)$ & (4) & (5) & $(6)$ & (7) & $(8)$ \\
\hline$\beta 1: R O A D$ & $\begin{array}{c}-0.014 \\
(0.065)\end{array}$ & $\begin{array}{c}-0.033 \\
(0.062)\end{array}$ & $\begin{array}{c}-0.041 \\
(0.061)\end{array}$ & $\begin{array}{c}-0.031 \\
(0.061)\end{array}$ & $\begin{array}{c}-0.064 \\
(0.082)\end{array}$ & $\begin{array}{l}-0.066 \\
(0.076)\end{array}$ & $\begin{array}{l}-0.079 \\
(0.075)\end{array}$ & $\begin{array}{c}-0.074 \\
(0.074)\end{array}$ \\
\hline$\beta 2: P O S T$ & $-0.180^{* * * *}$ & $-0.182^{* * * *}$ & $-0.225^{* * *}$ & $-0.211^{* * * *}$ & $-0.198^{* *}$ & $-0.197^{* * *}$ & $-0.231^{* * * *}$ & $-0.223^{* * *}$ \\
\hline$\beta 3: R O A D \times P O S T$ & $\begin{array}{c}(0.037) \\
0.135^{*} \\
(0.075)\end{array}$ & $\begin{array}{c}(0.037) \\
0.142^{*} \\
(0.074)\end{array}$ & $\begin{array}{l}(0.044) \\
0.150^{* *} \\
(0.075)\end{array}$ & $\begin{array}{c}(0.044) \\
0.129^{*} \\
(0.075)\end{array}$ & $\begin{array}{c}(0.077) \\
0.175^{*} \\
(0.102)\end{array}$ & $\begin{array}{c}(0.075) \\
0.171^{*} \\
(0.099)\end{array}$ & $\begin{array}{c}(0.073) \\
0.179^{*} \\
(0.094)\end{array}$ & $\begin{array}{c}(0.076) \\
0.164^{*} \\
(0.096)\end{array}$ \\
\hline Hous ehold characteristics & No & Yes & Yes & Yes & No & Yes & Yes & Yes \\
\hline Weather shocks & No & No & Yes & Yes & No & No & Yes & Yes \\
\hline Food Assistance & No & No & No & Yes & No & No & No & Yes \\
\hline Observations (clusters) & $3616(172)$ & $3592(172)$ & $3592(172)$ & $3572(172)$ & $3343(164)$ & $3319(164)$ & $3319(164)$ & $3299(164)$ \\
\hline
\end{tabular}

Note: The unit of observations is rural households in the 2012 and 2016 ESS. Matched sample was created by kernel matching method based on propensity scores

(estimated based on the propensity score model in Table A2). The DID model in Equation 3 was estimated with the natural logarithm of per adult equivalent household annual consumption as the outcome variable. ROAD is a dummy indicating the treatment status $(1=$ treated; $0=$ control). POST is a dummy indicating post-treatment year $(1=2016 ; 0=2012)$. The coefficient estimate for $(\mathrm{ROAD} \times \mathrm{POST})$ indicates the ass ociation between rural road development and household consumption in 2016 . Weather shock controls include indicators about drought exposure based on NDVI. Assistance controls include the amount of transfer received, PSNP as sistance, and PSNP labor. Hous ehold characteristic controls include the number of adult equivalent, hous ehold head's age, sex, education level, marital status, and religion. See Table A1 for the descriptions of these controls. Cluster robust standard errors in parentheses. ${ }^{*}{ }^{* *}$, and ${ }^{* * *}$ indicate significance level of estimated impacts at $10 \%, 5 \%$, and $1 \%$ levels.

Table A4. Estimation results on household consumption by different matching methods

\begin{tabular}{|c|c|c|c|c|c|}
\hline & \multicolumn{3}{|c|}{ Kernel matching } & \multicolumn{2}{|c|}{ Nearest neighbor matching } \\
\hline & $\begin{array}{c}\text { Band width }=0.06 \\
(1)\end{array}$ & $\begin{array}{c}\text { Band width }=0.03 \\
(2)\end{array}$ & $\begin{array}{c}\text { Band width }=0.12 \\
(3)\end{array}$ & $\begin{array}{c}\text { Without caliper } \\
(4)\end{array}$ & $\begin{array}{c}\text { With caliper } \\
\text { (5) }\end{array}$ \\
\hline$\beta 1: R O A D$ & $\begin{array}{l}-0.066 \\
(0.076)\end{array}$ & $\begin{array}{l}-0.094 \\
(0.077)\end{array}$ & $\begin{array}{l}-0.069 \\
(0.069)\end{array}$ & $\begin{array}{l}-0.033 \\
(0.079)\end{array}$ & $\begin{array}{l}-0.030 \\
-0.085)\end{array}$ \\
\hline$\beta 2: P O S T$ & $\begin{array}{l}-0.197^{* * *} \\
(0.075)\end{array}$ & $\begin{array}{l}-0.253^{* * *} \\
(0.069)\end{array}$ & $-0.229^{* * * *}$ & $-0.309^{* * *}$ & $-0.315^{* * *}$ \\
\hline$\beta 3: R O A D \times P O S T$ & $\begin{array}{c}0.171^{*} \\
(0.099)\end{array}$ & $\begin{array}{l}0.198^{* * *} \\
(0.093)\end{array}$ & $\begin{array}{c}0.169^{*} \\
(0.088)\end{array}$ & $\begin{array}{l}0.224^{* *} \\
(0.090)\end{array}$ & $\begin{array}{l}0.208^{* *} \\
(0.099)\end{array}$ \\
\hline Household characteristics & Yes & Yes & Yes & Yes & Yes \\
\hline Observations (clusters) & $3319(164)$ & $3137(155)$ & $3366(166)$ & $1529(79)$ & $1287(70)$ \\
\hline
\end{tabular}

Note: The unit of observations is rural households in theESS 2014 and 2016, matched by kernel matching (columns 1 to 3) and one-to-onenearest neighbor matching (columns 4 and 5). Caliper was used (0.1) for the matching in column 5. The DID model in Equation 3 was estimated with the natural logarithm of per adult equivalent real consumption as the outcome variable. Household characteristics are controlled (see Table S1 in the Supplementary Materials for the descriptions of the variables). Cluster robust standard errors in parentheses. ${ }^{* * *}$, and $^{* * *}$ indicate significance level of estimated impacts at $10 \%, 5 \%$, and $1 \%$ levels. 
Figure A1. Estimated propensity scores
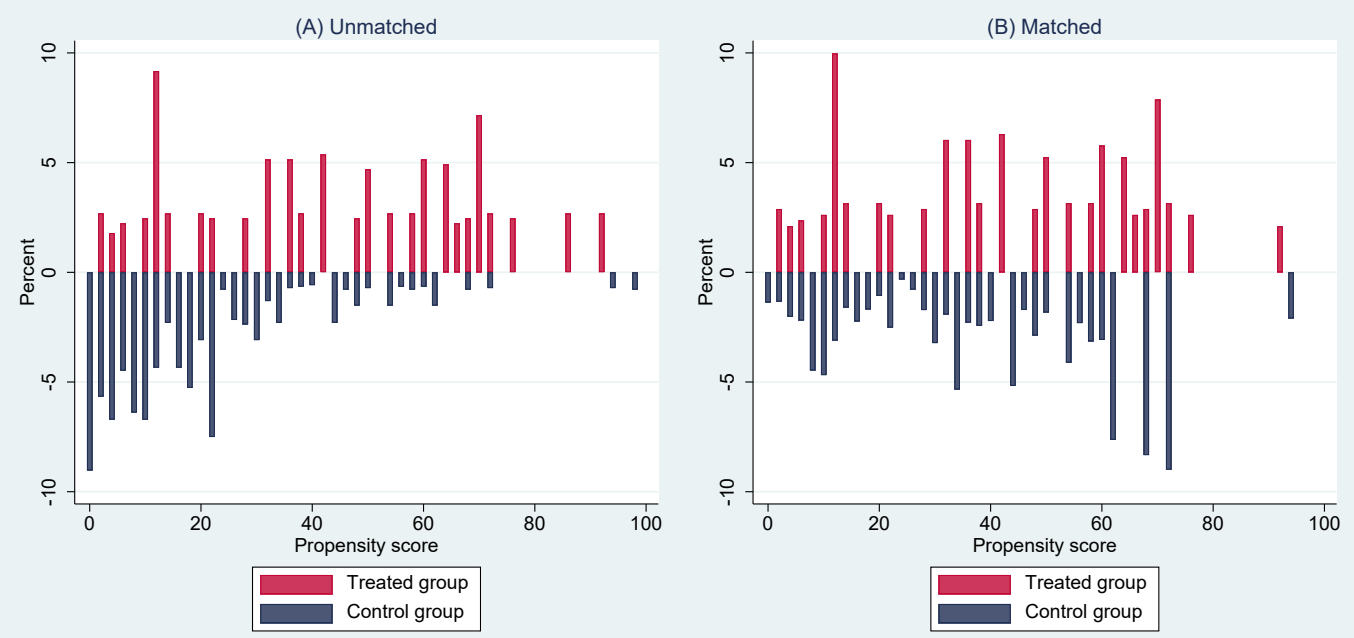

Note: The unit of observations is rural households in theESS, matched by kernel matching method based on propensity scores (estimated based on the propensity score model in Table A2). 


\section{Supplementary Materials (Online)}

\section{Figure S1 . Recently developed rural roads in Ethiopia}

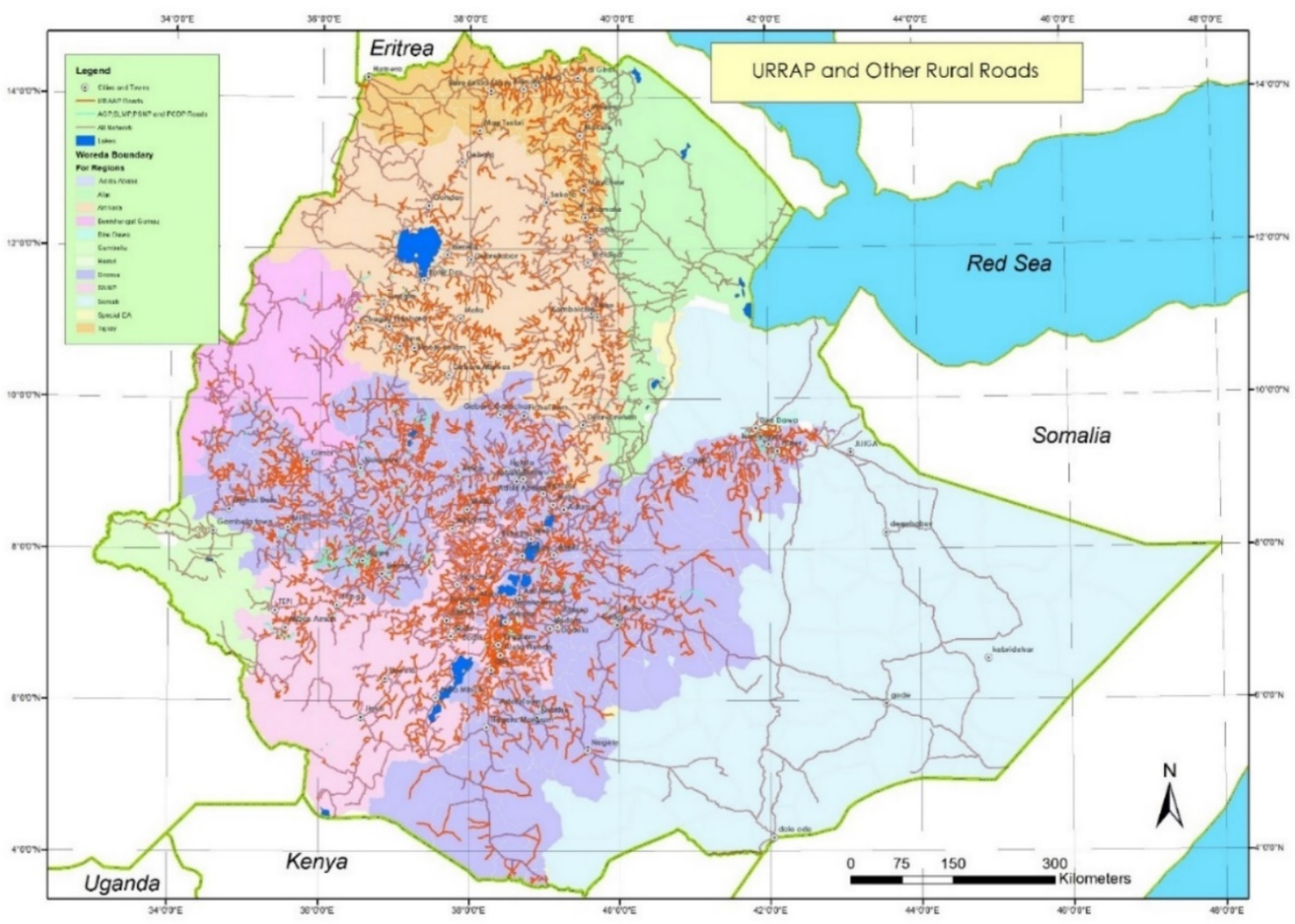

Source: The Ethiopiaroad database. 


\section{Table S1. List of variables}

\begin{tabular}{|c|c|c|}
\hline Name & Description & Data source \\
\hline Consumption & Per adult-equivalent annual consumption in 2016 prices & ESS \\
\hline Poor & 1 if per adult-equivalent annual consumption is lower than $\mathrm{Br}$. 4,360 (in 2016 prices); otherwise 0 & ESS \\
\hline Food ins ecurity & $\begin{array}{l}1 \text { if the household experienced a situation in which they did not have food enough to feed the members during } \\
\text { the last } 12 \text { months; otherwise } 0\end{array}$ & ESS \\
\hline Share of crop for sale & Share of harvested crop for sale & ESS \\
\hline Fertilizer use & 1 if the hous ehold used fertilizer during the season; otherwise 0 & ESS \\
\hline Wage job & 1 if any household member engaged in wage job during the last 12 months; otherwise 0 & ESS \\
\hline $\begin{array}{l}\text { Rural road developed between } 2010 \\
\text { and } 2014\end{array}$ & $\begin{array}{l}1 \text { if any all-weather roads developed within the boundary of the community between } 2010 \text { and } 2014 \text {; } \\
\text { otherwise } 0\end{array}$ & The Ethiopia road database \\
\hline Length of rural road (Kebele/Woreda) & Length of all-weather roads in the community/woreda & The Ethiopia road database \\
\hline Travel time to town(Kebele) & Travel time from the geometric center of the kebele to the nearest town (in minutes) & The Ethiopia road database \\
\hline RAI (Woreda) & Share of population within $2 \mathrm{~km}$ from any all-weather road in the kebele/woreda & $\begin{array}{l}\text { The Ethiopia road database, } \\
\text { WorldPop }\end{array}$ \\
\hline MAI (Kebele) & Sum of the population within 200 minutes from the Kebele center discounted by travel time & $\begin{array}{l}\text { The Ethiopia road database, } \\
\text { WorldPop }\end{array}$ \\
\hline Road density (Woreda) & $\begin{array}{l}\text { Length of all-weather roads per population at the Woreda in which the household resides (kilometer per } \\
\text { population) }\end{array}$ & $\begin{array}{l}\text { The Ethiopia road database } \\
\text { WorldPop }\end{array}$ \\
\hline Number of adult equivalent & Number of adult equivalent in the household & ESS \\
\hline Age of hous ehold head & Age of the hous ehold head (in years) & ESS \\
\hline Female-headed hous ehold & 1 if the hous ehold head is female; otherwise 0 & ESS \\
\hline Education level of hous ehold head & $\begin{array}{l}\text { The highest level of education achieved by the household head: no education, incomplete primary, complete } \\
\text { primary, incomplete secondary, complete secondary, post-secondary, adult education }\end{array}$ & ESS \\
\hline Marital status of household head & $\begin{array}{l}\text { Marital status of the household head: never married, married (monogamous), married (polygamous), divorced, } \\
\text { separated, widowed }\end{array}$ & ESS \\
\hline Religion of household head & Religion of the household head: orthodox, catholic, protestant, Muslim, traditional, pagan, wakifata, other & ESS \\
\hline Drought (Kebele) & 1 if $z$-score of NDVI $<0$; otherwise 0 & ESS \\
\hline Log of transfer received & Amount of transfer received by the household during the last 12 months (in 2016 prices) & ESS \\
\hline PSNP assistance & 1 if the hous ehold received PSNP as sistance during the last 12 months & ESS \\
\hline PSNP labor & 1 if the hous ehold participated in PSNP labor activity during the last 12 months & ESS \\
\hline Population density (Woreda) & Population density in the woreda & Census \\
\hline Poverty rate (Woreda) & Poverty headcount ratio at the woreda & HICES \\
\hline No education(Kebele) & Share of adults with no education in the kebele & Census \\
\hline Share of public piped water (Kebele) & Share of households with access to public piped water in the kebele & Census \\
\hline Share of electricity (Kebele) & Share of households with access to electricity for lighting in the kebele & Census \\
\hline Agro-climate zone(Woreda) & $\begin{array}{l}\text { Agro-ecological zones: tropic-warm/arid, tropic-warm/semiarid, tropic-warm/subhumid, tropic- } \\
\text { cool/subhumid, tropic-cool/semiarid, tropic-cool/humid }\end{array}$ & HarvestChoice/IFPRI \\
\hline Region & $\begin{array}{l}\text { Region in which the hous ehold resides: SNNPR, Amhara; Oromia, Tigray, B/Gumuz, D/Dawa, Harar, } \\
\text { Gambella, Afar }\end{array}$ & ESS \\
\hline
\end{tabular}




\section{Table S2. Estimation results on the log of household consumption}

\begin{tabular}{|c|c|c|c|c|c|c|c|}
\hline & \multirow[b]{2}{*}{$\begin{array}{l}\text { All } \\
(1) \\
\end{array}$} & \multicolumn{3}{|c|}{ Travel time threshold for $R E M O T E$} & \multicolumn{3}{|c|}{ z-score threshold for $D R O U G H T$} \\
\hline & & $\begin{array}{c}>120 \text { mins } \\
(2)\end{array}$ & $\begin{array}{c}>180 \text { mins } \\
(3)\end{array}$ & $\begin{array}{c}>240 \operatorname{mins} \\
(4)\end{array}$ & $\begin{array}{l}<0 \\
(5)\end{array}$ & $\begin{array}{c}<0.5 \\
(6)\end{array}$ & $\begin{array}{c}<-1.0 \\
(7)\end{array}$ \\
\hline$\beta 5: R O A D \times P O S T$ & $\begin{array}{l}0.171^{*} \\
(0.099)\end{array}$ & $\begin{array}{c}0.141 \\
(0.106)\end{array}$ & $\begin{array}{c}0.162 \\
(0.099)\end{array}$ & $\begin{array}{c}0.172^{*} \\
(0.101)\end{array}$ & $\begin{array}{c}0.076 \\
(0.168)\end{array}$ & $\begin{array}{c}0.177 \\
(0.130)\end{array}$ & $\begin{array}{c}0.132 \\
(0.103)\end{array}$ \\
\hline$\beta 7: R O A D \times R E M O T E \times P O S T$ & & $\begin{array}{c}0.143 \\
(0.206)\end{array}$ & $\begin{array}{c}0.126 \\
(0.290)\end{array}$ & $\begin{array}{c}0.121 \\
(0.145)\end{array}$ & & & \\
\hline$\beta 5+\beta 7$ : Effects on $\mathrm{HHs}$ in remote communities & & $\begin{array}{c}0.280 \\
(0.174)\end{array}$ & $\begin{array}{c}0.275 \\
(0.235)\end{array}$ & $\begin{array}{l}0.293^{* * *} \\
(0.054)\end{array}$ & & & \\
\hline$\beta 7: R O A D \times D R O U G H T \times P O S T$ & & & & & $\begin{array}{c}0.176 \\
(0.201)\end{array}$ & $\begin{array}{c}0.003 \\
(0.186)\end{array}$ & $\begin{array}{c}0.268 \\
(0.252)\end{array}$ \\
\hline$\beta 5+\beta 7$ : Effects on HHs in drought communities & & & & & $\begin{array}{l}0.252^{* * 6} \\
(0.107)\end{array}$ & $\begin{array}{c}0.180 \\
(0.129) \\
\end{array}$ & $\begin{array}{l}0.400^{*} \\
(0.227) \\
\end{array}$ \\
\hline
\end{tabular}

Note: The unit of observations is the matched sample of rural hous eholds in the 2012 and 2016 ESS. The DID models in Equations 2 and 3 were estimated with the natural logarithm of per adult equivalent household annual consumption as the outcome variables. The coefficient estimate for $(\beta 5+\beta 7)$ indicates the association

between rural road development and the outcome among households in remote communities or households in communities hit by the drought. Household

characteristics are controlled (see Table S1 for the descriptions of the variables). Cluster robust standard errors in parentheses. ${ }^{* * *}$, and ${ }^{* * *}$ indicate significance level of estimated impacts at $10 \%, 5 \%$, and $1 \%$ levels.

\section{Table S3. Summary of results on assistance}

\begin{tabular}{lccc}
\hline & $\begin{array}{c}\text { PSNP } \\
\text { assistance } \\
(1)\end{array}$ & $\begin{array}{c}\text { Free food } \\
(2)\end{array}$ & $\begin{array}{c}\text { PSNP or } \\
\text { free food } \\
(3)\end{array}$ \\
\hline (A) All households & -0.049 & -0.037 & -0.065 \\
& $(0.040)$ & $(0.065)$ & $(0.089)$ \\
By travel time to town & & & \\
(B) $R E M O T E=1$ (travel time $\geq 240$ minutes) & 0.134 & 0.093 & 0.216 \\
& $(0.099)$ & $(0.119)$ & $(0.178)$ \\
(C) $R E M O T E=0$ (travel time $<240$ minutes) & -0.063 & -0.047 & -0.086 \\
& $(0.041)$ & $(0.069)$ & $(0.094)$ \\
By drought exposure & & & \\
(D) DROUGHT=1 (vegetation z-score $\leq-1.0)$ & -0.049 & -0.061 & -0.077 \\
& $(0.128)$ & $(0.082)$ & $(0.184)$ \\
(E) DROUGHT=0 (vegetation z-score $>-1.0)$ & -0.034 & -0.020 & -0.037 \\
& $(0.034)$ & $(0.076)$ & $(0.096)$ \\
\hline
\end{tabular}

Note: The unit of observations is the matched sample of rural households in the 2012 and 2016 ESS. The DID models in Equations 2 and 3 were estimated with differentoutcome variables in the columns: whether the household received the PSNP as sistance during the last year (column 1); whether the household received free food aid during the last year (column 2); and whether the hous ehold received either the PSNP assistance or food aid during the last year (column 3 ). The coefficient estimates for $(\beta 5+\beta 7)$ are reported, which indicates the as sociation between rural road development and the outcome among households in remote communities (row B) or households in communities hit by the drought (row D). Household characteristics are controlled (see Table S1 in the Supplementary Materials for the descriptions of the variables). Cluster robust standard errors in parentheses. $* * *$, and $* * *$ indicate significance level of estimated impacts at $10 \%, 5 \%$, and $1 \%$ levels. Tables in the Supplementary Materials report detailed results. 


\section{Table S4. Estimation results on agriculture}

\begin{tabular}{|c|c|c|c|c|c|c|c|}
\hline & \multirow[b]{2}{*}{$\begin{array}{l}\text { All } \\
(1)\end{array}$} & \multicolumn{3}{|c|}{ Travel time threshold for $R E M O T E$} & \multicolumn{3}{|c|}{ z-score threshold for $D R O U G H T$} \\
\hline & & $\begin{array}{c}>120 \text { mins } \\
(2)\end{array}$ & $\begin{array}{c}>180 \text { mins } \\
(3)\end{array}$ & $\begin{array}{c}>240 \text { mins } \\
(4)\end{array}$ & $\begin{array}{l}<0 \\
(5) \\
\end{array}$ & $\begin{array}{c}<-0.5 \\
(6)\end{array}$ & $\begin{array}{c}<-1.0 \\
(7)\end{array}$ \\
\hline (A) Share of crop sold & & & & & & & \\
\hline$\beta 5: R O A D \times P O S T$ & $\begin{array}{c}0.006 \\
(0.022)\end{array}$ & $\begin{array}{c}0.002 \\
(0.025)\end{array}$ & $\begin{array}{l}-0.004 \\
(0.023)\end{array}$ & $\begin{array}{l}-0.006 \\
(0.022)\end{array}$ & $\begin{array}{c}0.026 \\
(0.034)\end{array}$ & $\begin{array}{c}0.023 \\
(0.031)\end{array}$ & $\begin{array}{c}0.014 \\
(0.025)\end{array}$ \\
\hline$\beta 7: R O A D \times R E M O T E \times P O S T$ & & $\begin{array}{c}0.008 \\
(0.048)\end{array}$ & $\begin{array}{c}0.075 \\
(0.062)\end{array}$ & $\begin{array}{l}0.160^{* * *} \\
(0.058)\end{array}$ & & & \\
\hline$\beta 5+\beta 7$ : Effects on HHs in remote communities & & $\begin{array}{c}0.011 \\
(0.041)\end{array}$ & $\begin{array}{c}0.046 \\
(0.055)\end{array}$ & $\begin{array}{l}0.154^{* * *} \\
(0.054)\end{array}$ & & & \\
\hline$\beta 7: R O A D \times D R O U G H T \times P O S T$ & & & & & $\begin{array}{c}-0.042 \\
(0.041)\end{array}$ & $\begin{array}{c}-0.043 \\
(0.041)\end{array}$ & $\begin{array}{l}-0.060 \\
(0.046)\end{array}$ \\
\hline$\beta 5+\beta 7$ : Effects on HHs in drought communities & & & & & $\begin{array}{l}-0.016 \\
(0.025)\end{array}$ & $\begin{array}{l}-0.020 \\
(0.028)\end{array}$ & $\begin{array}{l}-0.046 \\
(0.039)\end{array}$ \\
\hline (B) Fertilizer use & & & & & & & \\
\hline$\beta 5: R O A D \times P O S T$ & $\begin{array}{c}0.008 \\
(0.036)\end{array}$ & $\begin{array}{c}-0.002 \\
(0.038)\end{array}$ & $\begin{array}{l}-0.009 \\
(0.035)\end{array}$ & $\begin{array}{l}-0.019 \\
(0.035)\end{array}$ & $\begin{array}{c}-0.001 \\
(0.058)\end{array}$ & $\begin{array}{c}0.037 \\
(0.051)\end{array}$ & $\begin{array}{l}-0.022 \\
(0.066)\end{array}$ \\
\hline$\beta 7: R O A D \times R E M O T E \times P O S T$ & & $\begin{array}{c}0.051 \\
(0.089)\end{array}$ & $\begin{array}{c}0.125 \\
(0.143)\end{array}$ & $\begin{array}{l}0.376^{* * *} \\
(0.091)\end{array}$ & & & \\
\hline$\beta 5+\beta 7$ : Effects on HHs in remote communities & & $\begin{array}{c}0.048 \\
(0.082)\end{array}$ & $\begin{array}{c}0.066 \\
(0.131)\end{array}$ & $\begin{array}{l}0.357^{* * * *} \\
(0.085)\end{array}$ & & & \\
\hline$\beta 7: R O A D \times D R O U G H T \times P O S T$ & & & & & $\begin{array}{c}0.015 \\
(0.070)\end{array}$ & $\begin{array}{l}-0.065 \\
(0.074)\end{array}$ & $\begin{array}{l}0.173^{* *} \\
(0.079)\end{array}$ \\
\hline$\beta 5+\beta 7$ : Effects on $\mathrm{HHs}$ in drought communities & & & & & $\begin{array}{c}0.014 \\
(0.042) \\
\end{array}$ & $\begin{array}{c}-0.028 \\
(0.051) \\
\end{array}$ & $\begin{array}{l}0.151^{* *} \\
(0.069)\end{array}$ \\
\hline
\end{tabular}

Note: The unit of observations is the matched sample of rural hous eholds in the 2012 and 2016 ESS. The DID models in Equations 2 and 3 were estimated with the share of crop sold by the household (A) and the binary indicator about the fertilizer use by the household (B) as the outcome variables. The coefficient estimate for $(\beta 5+\beta 7)$ indicates the association between rural road development and the outcomes among households in remote communities or hous eholds in communities hit by the drought. Household characteristics are controlled (see Table S1 for the descriptions of the variables). Cluster robust standard errors in parentheses. ${ }^{*},{ }^{* *}$, and ${ }^{* * *}$ indicate significance level of estimated impacts at $10 \%, 5 \%$, and $1 \%$ levels. 
Table S5. Estimation results on wage jobs

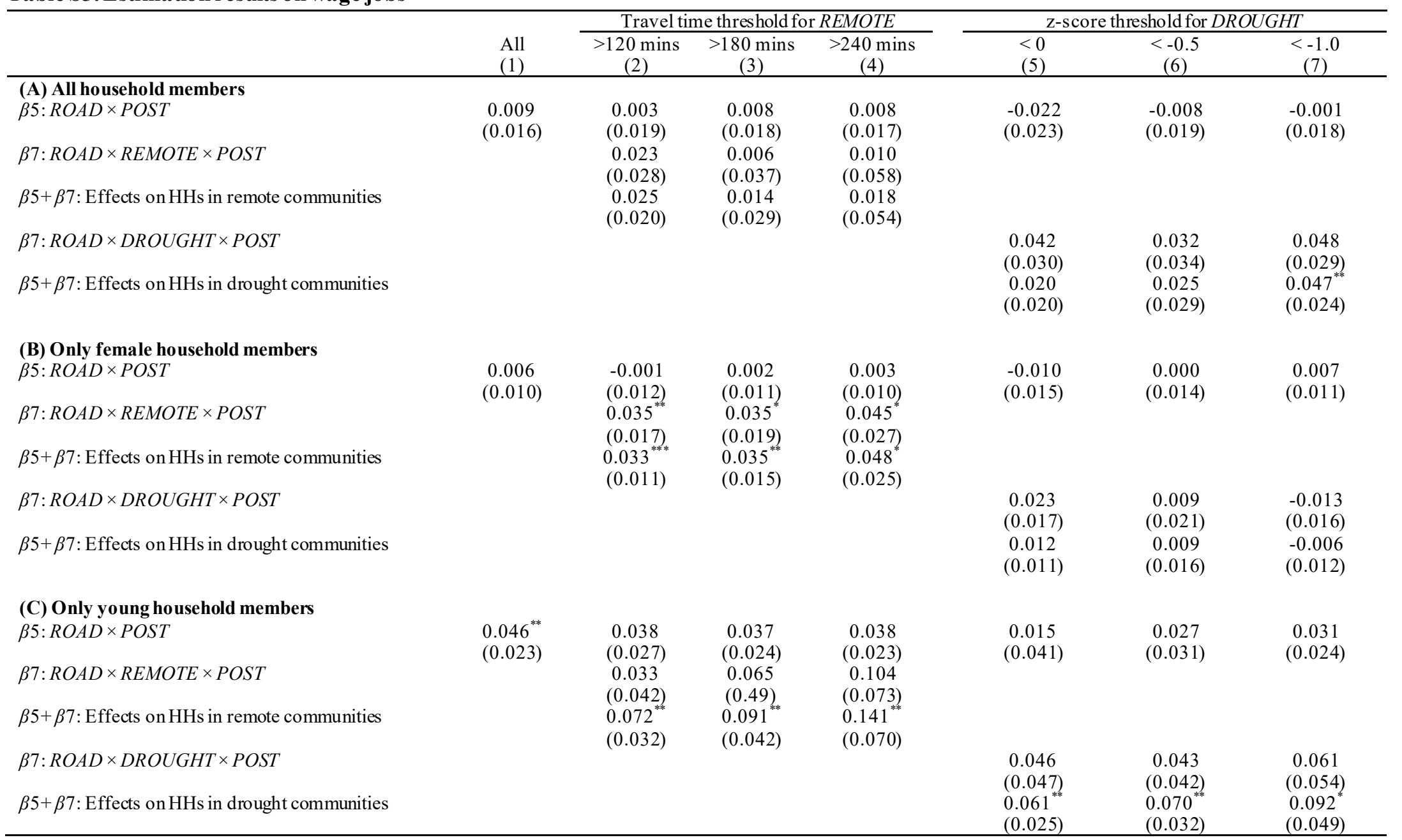

Note: The unit of observations is the matched sample of rural hous eholds in the ESS. The DID models in Equations 3 and 4 were estimated with the following outcome variables: (A) the share of household members who engaged in wage jobs $(\%),(B)$ the share of female household members who engaged in wage jobs $(\%)$, and $(C)$ the share of young hous ehold members who engaged in wage jobs (\%). The coefficient estimate for $(\beta 5+\beta 7)$ indicates the as sociation between rural road development and the outcomes among households in remote communities or hous eholds in communities hit by the drought. Hous ehold characteristics are controlled (see Table S1 for the descriptions of the variables). Cluster robust standard errors in parentheses. ${ }^{*},{ }^{*}$, and ${ }^{* * *}$ indicate significance level of es timated impacts at $10 \%, 5 \%$, and $1 \%$ levels. 